\title{
Amniotic Fluid Embolism with Haemostasis Complications: Primary Fibrinogenolysis or Disseminated Intravascular Coagulation?
}

\author{
C. Biron-Andréania ${ }^{a}$ E. Morau ${ }^{b} \quad$ J.-F. Schved ${ }^{a} \quad$ B. Hédon ${ }^{c} \quad H$. Dechaud $^{c}$ \\ a Laboratoire d'Hématologie, Centre Hospitalier Universitaire, b'Département d'Anesthésie-Réanimation B, et \\ 'Fédération de Gynécologie-Obstétrique, Montpellier, France
}

\section{Key Words}

Amniotic fluid embolism • Primary fibrinogenolysis . Disseminated intravascular coagulation $\cdot$ Haemostasis

\begin{abstract}
Amniotic fluid embolism (AFE) is characterized by the passage of amniotic fluid (AF) into the maternal circulation during or just after childbirth. AFE is a rare disorder occurring in $1 / 8,000$ to $1 / 80,000$ deliveries but with a maternal morbidity ranging from $26 \%$ in a recent report to $86 \%$ in earlier ones [1-3]. In patients who survive, AFE may affect coagulation resulting in severe bleeding $[3,4]$. While disseminated intravascular coagulation (DIC) is usually seen in such cases, we reported a case of AFE in which the hemostatic abnormalities were compatible with primary fibrinogenolysis rather than with DIC.
\end{abstract}

Copyright $@ 2003$ S. Karger AG, Basel

\section{Case Report}

A 30-year-old G1P1 woman was admitted at 37 weeks and 5 days of gestation because of a premature rupture of membranes. Suddenly during labor, she presented with dyspnea and hypotension followed within minutes by cardiorespiratory arrest. The laboratory results were: hemoglobin $9.6 \mathrm{~g} / \mathrm{dl}$ (normal values not taking pregnancy into account: $12-16)$, platelets $115 \mathrm{~g} / \mathrm{l}(150-400)$, prothrombin time $43 \%$ (80-100), fibrinogen $0.3 \mathrm{~g} / \mathrm{l}(1.9-4)$, factor II $62 \%$ (70-140), factor V $6 \%$ (60-140), factor VII 146\% (70-140), factor X 70\% (70-150), fac- tor VIII 31\% (50-150), antithrombin 57\% (80-130), absence of soluble fibrin, fibrin degradation products $150 \mu / \mathrm{ml}(<10)$, D-dimer $20 \mu \mathrm{g} / \mathrm{ml}(<0.5)$, tissue plasminogen activator (t-PA) $35 \mathrm{ng} / \mathrm{ml}(1-$ 12 ), and plasmin inhibitor (previously $\alpha_{2}$-antiplasmin) $<5 \%(70$ 120). These values were quite similar to another blood sample drawn after $20 \mathrm{~min}$ except for the hemoglobin which fell to $5.2 \mathrm{~g} / \mathrm{dl}$. The following diagnoses were excluded: anaphylaxis, septic shock, pulmonary embolism, preeclampsia, HELLP syndrome, placenta previa or retroplacental hematoma. Therefore the most likely diagnosis was AFE. A symptomatic management was instituted including fresh frozen plasma (4 units), packed red cells (4 units) and fibrinogen concentrate infusion. A cesarean section was performed. However, an hemostatic hysterectomy was required to stop the bleeding. The postoperative course was uneventful. The woman survived without any sequelae while the neurological prognosis for the child remained uncertain. All the hemostasis parameters were within the normal range when the patient was discharged 7 days later.

\section{Discussion}

The distinction between primary fibrinogenolysis and DIC with secondary fibrinolysis is often difficult to draw. It is complicated by the changes in the coagulation and fibrinolytic systems during normal pregnancy. However, the absence of clinical evidence of systemic thrombosis (hepatic and renal tests remain normal) and some biological data may suggest predominant fibrinogenolysis: a normal platelet count, a very low fibrinogen level and factor V level in contrast to normal factor II, VII, X ones, the absence of soluble fibrin, a high level of fibrin degradation

\begin{tabular}{ll}
\hline KARGER & ( ) 2003 S. Karger AG, Basel \\
1424-8832/03/0333-0170\$19.50/0 \\
$\begin{array}{l}\text { Fax +4161306 12 34 } \\
\begin{array}{l}\text { E-Mail karger@karger.ch } \\
\text { www.karger.com }\end{array}\end{array}$ & $\begin{array}{l}\text { Accessible online at: } \\
\text { www.karger.com/pht }\end{array}$
\end{tabular}

C. Biron-Andréani

Laboratoire d'Hématologie, Hôpital Saint-Eloi

80, avenue Augustin Fliche

FR-34295 Montpellier, Cedex 5 (France)

Tel. +334673370 31, Fax +334673370 36, E-Mail c-biron@chu-montpellier.fr 
products, and a very low plasmin inhibitor level with high values of t-PA. Antithrombin levels decreased slightly during pregnancy reaching values published in the literature ranging from 40 to $132 \%$ during the third trimester [5].

The mechanisms by which the AFE could have been associated with primary fibrinogenolysis remain to be elucidated. The potential of the AF to induce coagulation is linked to the presence of a functionally active tissue factor and a factor $X$ activating substance $[6,7]$. But AF also contains a t-PA, a urokinase-like plasmin activator which can enhance fibrinolysis [8]. Using thromboelastograph analysis, Liu et al. [9] found a tendency toward increased lysis with the addition of full-term AF, though this was not significant. Moreover a recent study has found that all patients suffering from premature membrane rupture with confirmed intrauterine infection and two thirds of those without infection showed an elevated AF tumor necrosis factor- $\alpha$ (TNF- $\alpha)$ and interleukins (IL-1, IL-6) [10]. This is of interest since TNF- $\alpha$ may be considered as a major factor for triggering fibrinolysis [11].

In conclusion, AFE is a rare and dramatic obstetric complication associated with coagulopathy. Nevertheless, generalized fibrinolysis was the predominant feature; quick recognition of the event and aggressive treatment may enable survival.

\section{References}

1 Gilbert WM, Danielsen B: Amniotic fluid embolism: Decreased mortality in a populationbased study. Obstet Gynecol 1999;93:973977.

2 Morgan M: Amniotic fluid embolism. Anesthesia 1979;34:20-32.

3 Stolte LAM, Lim HT, Van Arkel C, et al: Amniotic fluid embolism; in Fairwater DVI, Eskes TKAB (eds): Amniotic Fluid Research and Clinical Application. Amsterdam, Excerpta Medica, 1973, pp 313-332.

4 Ratnoff OD, Vosburgh GH: Observations on clotting defect in amniotic fluid embolism. N Engl J Med 1952;247:970.

5 Stirling Y, Woolf L, North WR, Seghatchian MJ, Meade TW: Haemostasis in normal pregnancy. Thromb Haemost 1984;52:176-182.
6 Lockwood CJ, Bach R, Guha A, et al: Amniotic fluid contains tissue factor, a potent initiator of coagulation. Am J Obstet Gynecol 1991;165: 1335-1341.

7 Courtney L, Allington M: Effect of the amniotic fluid on blood coagulation. Br J Haematol 1972;22:353-355.

8 Koh SCL, Anandakumar C, Arulkumaran S, et al: Amniotic fluid plasminogen activators and inhibitors and thrombin anti-thrombin complex levels during second trimester and labour. Fibrinolysis 1995;9:121-126.

9 Liu EHC, Shailaja S, Koh SCL, Lee TL: An assessment of the effects on coagulation of midtrimester and final-trimester amniotic fluid on blood by thromboelastograph analysis. Anesth Analg 2000;90:333-336.
10 Shobokshi A, Shaarawy M: Maternal serum and amniotic fluid cytokines in patients with preterm premature rupture of membranes with and without intrauterine infection. Int $\mathrm{J}$ Gynaecol Obstet 2002;79:209-215.

11 van Hinsbergh VW, Bauer K, Kooistra T, Kluft C, Dooijewaard G, Sherman ML, et al: Progress of fibrinolysis during tumor necrosis factor infusions in humans. Concomitant increase in tissue-type plasminogen activator, plasminogen activator inhibitor type-1, and fibrin(ogen) degradation products. Blood 1990;76:22842289. 